Participatory Educational Research (PER)

Vol. 2(1), pp.44-56, April, 2015

Available online at http://www.partedres.com

ISSN: $2148-6123$

http://dx.doi.org/10.17275/per.14.19.2.1

\title{
The Effect of Instructional Technology and Material Design Course to Teacher Candidates' Gaining of Technological Pedagogical Content Knowledge Competencies
}

\author{
Süleyman Burak Tozkoparan* \\ Mevlana (Rumi) University, Education Faculty Konya, Turkey \\ Muhammet Emre Kıliç \\ Mevlana (Rumi) University, Education Faculty, Konya, Turkey
}

Ertuğrul Usta

Necmettin Erbakan University, Education Faculty, Konya, Turkey

\begin{tabular}{|c|c|}
\hline Article history & ntent \\
\hline $\begin{array}{l}\text { Received: } \\
29.11 .2014\end{array}$ & $\begin{array}{l}\text { Knowledge (TPACK) Competencies of teacher candidates in Turkish } \\
\text { Teaching department of Mevlana (Rumi) University and the effect of }\end{array}$ \\
\hline $\begin{array}{l}\text { Received in revised form: } \\
05.01 .2015\end{array}$ & $\begin{array}{l}\text { Instructional Technology and Material Design (ITMD) Course on TPACK. } \\
\text { The study is a study of quantitative type and single-group pretest-posttest } \\
\text { experimental design has been used. The study has been conducted in the }\end{array}$ \\
\hline $\begin{array}{l}\text { Accepted: } \\
06.01 .2015\end{array}$ & $\begin{array}{l}\text { spring semester of } 2013 / 2014 \text { academic year, candidates who are studying } \\
\text { in 2nd class of Turkish teaching department in Education Faculty of }\end{array}$ \\
\hline Key words: & Mevlana (Rumi) University. In this study, Sahin (2011)'s Technological \\
\hline $\begin{array}{l}\text { TPACK, Preservice Teacher } \\
\text { Education, ICT Integration }\end{array}$ & $\begin{array}{l}\text { Pedagogical Content Knowledge (TPACK) Survey has been used. The } \\
\text { survey is a } 5 \text { point likert type survey and it has } 47 \text { items in total. This survey } \\
\text { has been applied as pre-test in the classroom to the students who } \\
\text { participated in the study. After a period of } 10 \text { weeks, the same survey has } \\
\text { been applied again to the same students as post-test and thus, pre-test/post- } \\
\text { test data has been obtained for the study. According to the findings of the } \\
\text { study, TPACK levels of Turkish teacher candidates who participated in the } \\
\text { study have been differentiated significantly in terms of all the subscales of } \\
\text { the survey. In the light of this study, it can be said that TPACK model plays } \\
\text { a leading role on the subject of teachers' needs about technology, pedagogy } \\
\text { and content in order to ensure professional development of teachers. }\end{array}$ \\
\hline
\end{tabular}

\section{Introduction}

There have been the subjects of many studies in the literature that teachers should have what kind of teacher knowledge, skills and abilities in their professional life. Knowledge that a teacher should have can be categorized as content knowledge, pedagogical field knowledge and

\footnotetext{
* Correspondence: Res. Assist., Mevlana (Rumi) University, Faculty of Education, Computer and Instructional Technologies Department, Konya, Turkey
} 
curriculum knowledge (Shulman, 1986). This definition by Shulman (1986) has become a generally accepted definition both in the literature and in the field of teacher education (Segall, 2004). Content knowledge is teacher's knowledge that will be learned or taught and it has vital importance for the teaching profession (Koehler and Mishra, 2009). In view of Baxter and Lederman (1999), Pedagogical field knowledge is the concept related to teachers' knowledge, performs and why they make.

In studies conducted at primary school level, it's reached that if teacher knows how to use Information and Communication Technologies (ICT) in the process of students' thinking, expression and knowledge creation, a positive effect arises as a result (Loveless and Dore 2002; Angeli and Valanides, 2005). In literature, awareness rising of teachers in the subject of using of technology for educational purposes is emphasized and also it has vital role in all the studies for enabling the teaching process (Becker, 2001; Brand, 1998; Davis and Falba, 2002; Angeli and Valanides, 2009; Dawson, Pringle and Adams, 2003; Pringle, Dawson and Adams, 2003; Thompson, Schmidt and Davis, 2003; Mumtaz, 2000). In addition to this, the Turkish Education Association (2009) has emphasized in their teacher qualifications report that teachers should have knowledge about recent developments in the field of teachers, the basic concepts, tools and structures of their fields, integration of content that they will teach with technology.

The development of technology and entering into every area of our lives, and also has affected the education process. Technological innovation, the creation of technological infrastructure, ensuring integration of technology are the factors affecting the use of technology in education (Yurdakul and Odabaş1, 2013). There are many integration models in order to ensure the integration of technology in education (Mazman and Usluel, 2011). In this integration models seems a trend that from technology oriented to pedagogy oriented approaches (Yurdakul and Odabaş1, 2013). Technological Pedagogical Content Knowledge is an integration current model developed for the integration of technology in education (Koehler and Mishra, 2005; Mishra and Koehler, 2006; Angeli and Valanides, 2005). TPACK model has been built on the Shulman(1986, 1987) study of pedagogical content knowledge for using technological elements effectively in the educational process (Koehler and Mishra, 2009). TPACK is recognized as an efficient model for helping solutions of issue which integration of ICT to classroom teaching and learning activities (Hewitt, 2008). TPACK is based on 3 different sources, which are technological content knowledge, technological pedagogical knowledge; and pedagogical content knowledge, and their interaction (Chai, Ling Koh, Tsai, and Lee Wee Tan, 2011; Mishra and Koehler, 2006; Koehler and Mishra, 2009). TPACK model has been adopted as a theoretical basis for structuring the curriculum of teacher education programs for the integration of ICT (Angeli and Valanides, 2009). These concepts in literature can be summarized as follows (Archambault and Barnett, 2010; Graham, 2011; Cox and Graham, 2009; Gess-Newsome, 1999; Mishra and Koehler, 2009; Cochran, 1991; Shulman, 1986; Chai, Ling Koh, Tsai, and Lee Wee Tan, 2011; Koehler and Mishra, 2006; Cox, 2008).

- Technological Knowledge : Knowledge on how to run a computer or related software.

- Pedagogical Knowledge : Knowledge on how to plan teaching, how to teach, how to manage students, how to behave according to individual differences.

- Content Knowledge : Subject knowledge, such as language teaching, mathematics, social sciences, etc. 
- Technological Content Knowledge : Knowledge on how a content can be investigated or teach with the help of technology. For example; giving information about earthquakes with the help of internet and the use of technological devices to study.

- Pedagogical Content Knowledge : Knowledge on the ways of presentation and formulation in order to make the subject understandable to others or students

- Technological Pedagogical Knowledge : Knowledge on how technology can facilitate the pedagogical approaches.

- Technological Pedagogical Content Knowledge (TPACK): Knowledge on how to make student learning easier on a specific content with the appropriate pedagogy and technology

In the light of these, it can be said that TPACK model consists both components of Technology Information, Content Knowledge, Pedagogical Knowledge and intersection of this knowledge field types (Technological Content Knowledge, Technological Pedagogical Knowledge, Pedagogical Content Knowledge) (Yurdakul and Odabaş1, 2013, p.43, Timur and Yaşar, 2011, p.842). In their study, Timur and Yaşar (2011) take Technological Pedagogical Content Knowledge as Technological Pedagogical Content Knowledge. Model is defined as teachers, using technology for making an effective teaching, practice effectively Pedagogical Content Knowledge with educational technologies in their classrooms. In their study, "Technological Pedagogical Content Knowledge Self-Confidence Scale" developed by Graham, Burgoyne, Cantrell, Smith and Harris (2009) was adapted into Turkish. As a result of their application, the factor structure of the original scale is the same Turkey conditions and also is emphasized that this scale can be used for determining teachers' technological pedagogical content knowledge self-confidence.

One of first the studies on the concept of Technological Pedagogical Content have been studied by Keating and Evans (Yurdakul and Odabaş1, 2013, p. 49). In the literature, there are different concepts, have close meaning with TPACK, used by researchers (Niess, 2005; Beaudin and Hadden, 2004; Margerum-Leys and Marx, 2002). However, at the present time it can be said that the concept accepted and emphasized by the researchers is TPACK. On the other hand, there have been found many measuring tools that their reliability and validity studies have been conducted to measure TPACK skills. Margerum-Leys and Marx (2002) have been studied the elements of technology education knowledge under content knowledge, pedagogical knowledge and pedagogical content. Educational technology content knowledge is taken as using technological devices and Information and Communication Technology knowledge. In other respects, Pamuk (2011), has been used TPACK framework in his study to examine teacher candidates' technology use. Erdoğan and Şahin (2010) have conducted a study which analyses mathematics teachers' TPACK according to some variables and analyses whether TPACK predicts student achievement or not. In addition to this, male math teacher candidates differentiate positively to women math" teacher candidates in terms of Technological Pedagogical Content Knowledge and there is a significant difference between elementary mathematics teacher candidates and secondary mathematics teacher candidates in terms of TPACK and also TPACK predicts mathematics teachers' achievement levels. Furthermore, in their study, Yurdakul, Odabasi, Kilicer, Coklar, Birinci and Kurt (2012) have been developed a scale based on TPACK model with 995 participants and they have been demonstrated the reliability and the validity of their scale, also they have been performed the scale's exploratory and confirmatory factor analyses. Consequently, they have been stated that the scale they have developed is a valid and reliable tool in measuring 
TPACK of teacher candidates. Moreover, they have been remarked that experimental studies should be done to observe the TPACK development of teacher candidates. Similarly, Burgoyne, Graham and Sudweeks (2010) have been developed a scale in order to measure student's level of self-efficacy about the concepts that form the TPACK model and they have been examined the reliability and validity of the scale and they have been carried out a confirmatory factor analysis. In addition, there are other researchers who have been conducted a scale development study on TPACK (Archambault and Crippen, 2009; Archambault and Oh-Young, 2009). Koh, Chai and Tsai (2010) in their study on teachers in Singapore, they have been adapted a scale by the items of the study of Schmidt, Baran, Thompson, Mishra, Koehler and Shin (2009) according to the conditions of Singapore and they have been examined the validity of the scale they have developed and made a factor analysis. In the study by Archambault and Barnett (2010), they have been studied the validity of the TPACK model with 596 teacher participants and they have been conducted a factor analysis and they have been concluded that there are three factors in the scale they have developed including technology, pedagogy and content factors, additively, they have been stated that only the technology concept can be separated from the rest of these factors, however, thereby the concepts of pedagogy and content concepts are intertwined and complicated concepts, it is difficult to measure them.

Since before now, it's known that there are many researches about integration of technology to educational process in general and the learning and teaching process in particular. With the technological devices, it has become possible to use new methods and techniques in the learning process, in addition to this, many innovations and arrangements have been made in the regulation of learning environments. Many researchers emphasize that effective use of instructional technology has the potential to improve education system (Jonassen and Reeves, 1996; Çağıltay, Çakıroğlu, Çağıltay and Çakıroğlu, 2001; Usta and Korkmaz, 2010). Despite the widespread use of technology in the educational process and substantial changes in education programs of education faculties, it can be said that Instructional Technology and Material Design (ITMD) course is the only course that enable teacher candidates to use instructional technology correctly and include applications to integrate instructional technology in any subject field or course. Unfortunately, it's known in academia in Turkey that instructors of this course are people who are not experts in the field of instructional technology, expertise is not taken into account in the distribution of courses in faculties of education and ITMD course is seen as just an ordinary training course. In this case, it can not be possible to upskill teacher candidates in using skills of relevant technologies related to subjects accurately and effectively, and an understanding of how to use technology and where by teacher candidates can not be generated sufficiently. Therefore, the experience teacher candidates gain or not in the process of training affects their beliefs and attitudes towards the teaching profession (Çağıltay et al. 2001). From the moment they stepped into the teaching profession, teacher candidates' integration of technology to lessons correctly in their professional lives undoubtedly depends on many variables. One of these variables can be such as devices provided by computers and internet and can be used for educational purposes and social media, Another one can be level of ability to use the different methods and techniques in the classroom effectively in the presentation of a lesson. Starting from these basic assumptions, in this study, it's aimed to determine the Competencies of teacher candidates' TPACK and it's intended to describe the effects of ITMD course on these competencies. 


\section{Aim of the study}

The aim of this study is to determine TPACK Competencies of teacher candidates in Turkish Teaching department of Mevlana (Rumi) University Faculty of Education and is to determine whether ITMD course has a significant effect on these competencies.

For this purpose, the following questions have been sought;

(1) What areTurkish teacher candidates the pre-test and post-test scores according all subfactors related to TPACK?

(2) Does ITMD Course lead to a significant differentiation onTurkish teacher candidates' TPACK skills?

\section{Methodology}

The study is a study of quantitative type and single-group pretest-posttest experimental design has been used. This type of design can be defined as the repeated measures design. It can be said that the design has single factor (time dependent two measurements) structure (Büyüköztürk, 2007; Karasar, 2006).

\section{Participants}

The study has been conducted in the spring semester of 2013/2014 academic year, with 17 male, 20 female, a total of 37 teacher candidates who are studying in 2nd class of Turkish teaching department in Education Faculty of Mevlana (Rumi) University.

Table 1. Participants

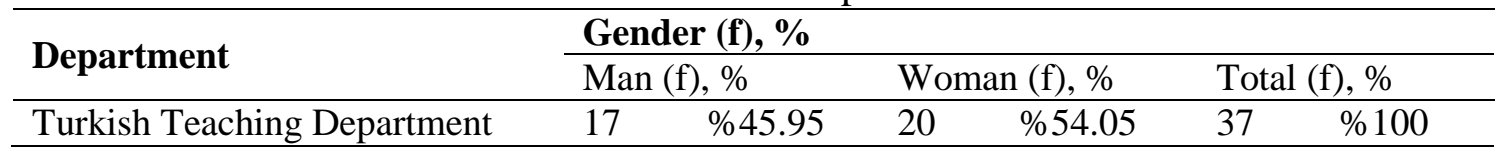

\section{Instruments}

In this study, Sahin (2011)'s TPACK Survey was used. The survey consists of 7(Technology Knowledge, Pedagogy Knowledge, Content Knowledge, Technological Pedagogical Knowledge, Pedagogical Content Knowledge, Technological Content Knowledge, Technological Pedagogical Content Knowledge) subscales and 47 items in total. The survey is a 5 point likert type survey ("1=not at all", "2=little", "3=moderate", "4=quite", and " $5=$ complete").

\section{The Course and Data Collection Process}

TPACK survey has been applied as pre-test in the classroom to the students who participated in the study. After a period of 10 weeks, the same survey has been applied again to the same students as post-test and thus, pre-test/post-test data has been obtained for the study. In the 10-weeks experimental period, the subjects in the context of TPACK such as digital storytelling, educational short films, web site design, e-book design, web 2.0 tools and educational use of social media has been pointed in classroom to the Turkish teacher candidates and assignments for each of 
the skills acquired about the related tools have been given that enable students to practice them in a subject from primary school Turkish course program.

\section{Analysis of Data}

SPSS program has been used in order to analyze the data and the data obtained from pretest/post-test has been entered to the program. For each subscale, pre-test and post-test data were collected and the scores have been found. These scores have been compared with T-test.

\section{Findings}

In this section, it has been examined separately that whether Turkish teacher candidates' TPACK survey scores differentiate or not according to the pre-test and the post-test scores of each subscale(Technology Knowledge, Pedagogy Knowledge, Content Knowledge, Technological Pedagogical Knowledge, Pedagogical Content Knowledge, Technological Content Knowledge, Technological Pedagogical Content Knowledge) of the survey. In addition, it has been examined that whether there is a significant relation or not between male and female teacher candidates TPACK survey scores of the pre-test and the post-test.

After collecting Turkish teacher candidates scores they got from the survey's Technology Knowledge subscale in the pre-test and the post-test, T-test has been conducted. The test results are listed in the Table 2 below.

Table 2. T-test results of Technology Knowledge Subscale of the TPACK Survey

\begin{tabular}{llcllll}
\hline Subscale & $\mathbf{N}$ & $\overline{\mathbf{X}}$ & $\mathbf{S}$ & sd & t & p \\
\hline Technology & 37 & 47.05 & 8.75 & & & \\
Knowledge (Pre-Test) & & & & 36 & 3.30 & .002 \\
\hline $\begin{array}{l}\text { Technology } \\
\text { Knowledge (Post-Test) }\end{array}$ & 37 & 53.95 & 8.00 & & & \\
\hline
\end{tabular}

When Table 2 is analyzed, it can be said that the pre-test and the post-test scores of teacher candidates participated in the study have been differentiated significantly for Technology Knowledge subscale of the TPACK Survey and it is obvious that the post-test scores of the teacher candidates have been made a differentiation when compared to the pre-test scores $(\mathrm{t}=3.30$, $\mathrm{p}=.002<.05)$.

After collecting Turkish teacher candidates scores they got from the survey's Pedagogical Knowledge subscale in the pre-test and the post-test, T-test has been conducted. The test results are listed in the Table 3 below.

Table 3. T-test results of Pedagogical Knowledge Subscale of the TPACK Survey

\begin{tabular}{lccccccc}
\hline Subscale & & $\mathbf{N}$ & $\overline{\mathbf{X}}$ & $\mathbf{S}$ & $\mathbf{S d}$ & $\mathbf{t}$ & $\mathbf{p}$ \\
\hline $\begin{array}{l}\text { Pedagogical } \\
\text { Knowledge } \\
\text { Test) }\end{array}$ & (Pre- & 37 & 18.60 & 5.16 & & & \\
\hline $\begin{array}{l}\text { Pedagogical } \\
\begin{array}{l}\text { Knowledge } \\
\text { Test) }\end{array}\end{array}$ & (Post- & 37 & 21.87 & 3.52 & & 3.05 & .004 \\
\hline
\end{tabular}


When Table 3 is analyzed, it can be said that the pre-test and the post-test scores of teacher candidates participated in the study have been differentiated significantly for Pedagogical Knowledge subscale of the TPACK Survey and it is obvious that the post-test scores of the teacher candidates have been made a differentiation when compared to the pre-test scores $(\mathrm{t}=3.05$, $\mathrm{p}=.004<.05)$.

After collecting Turkish teacher candidates scores they got from the survey's Content Knowledge subscale in the pre-test and the post-test, T-test has been conducted. The test results are listed in the Table 4.

Table 4. T-test results of Content Knowledge Subscale of the TPACK Survey

\begin{tabular}{llcllll}
\hline Subscale & $\mathbf{N}$ & $\overline{\mathbf{X}}$ & $\mathbf{S}$ & Sd & t & p \\
\hline $\begin{array}{l}\text { Content Knowledge } \\
\text { (Pre-Test) }\end{array}$ & 37 & 19.03 & 4.49 & & & \\
\hline $\begin{array}{l}\text { Content Knowledge } \\
\text { (Post-Test) }\end{array}$ & 37 & 21.38 & 3.77 & & 2.18 & .036 \\
\hline
\end{tabular}

When Table 4 is analyzed, it can be said that the pre-test and the post-test scores of teacher candidates participated in the study have been differentiated significantly for Content Knowledge subscale of the TPACK Survey and it is obvious that the post-test scores of the teacher candidates have been made a differentiation when compared to the pre-test scores $(t=2.18, p=.036<.05)$.

After collecting Turkish teacher candidates scores they got from the survey's Technological Pedagogical Knowledge subscale in the pre-test and the post-test, T-test has been conducted. The test results are listed in the Table 5.

Table 5. T-test results of Technological Pedagogical Knowledge Subscale of the TPACK Survey

\begin{tabular}{|c|c|c|c|c|c|c|c|}
\hline Subscale & & $\mathbf{N}$ & $\overline{\mathbf{X}}$ & $\mathbf{S}$ & Sd & $\mathbf{t}$ & $\mathbf{p}$ \\
\hline $\begin{array}{l}\text { Technological } \\
\text { Pedagogical } \\
\text { (Pre-Test) }\end{array}$ & Knowledge & 37 & 12.14 & 4.46 & \multirow{2}{*}{36} & \multirow{2}{*}{3.29} & \multirow{2}{*}{.002} \\
\hline $\begin{array}{l}\text { Technological } \\
\text { Pedagogical } \\
\text { (Post-Test) }\end{array}$ & Knowledge & 37 & 14.77 & 2.55 & & & \\
\hline
\end{tabular}

When Table 5 is analyzed, it can be said that the pre-test and the post-test scores of teacher candidates participated in the study have been differentiated significantly for Technological Pedagogical Knowledge subscale of the TPACK Survey and it is obvious that the post-test scores of the teacher candidates have been made a differentiation when compared to the pre-test scores $(\mathrm{t}=3.29, \mathrm{p}=.002<.05)$.

After collecting Turkish teacher candidates scores they got from the survey's Pedagogical Content Knowledge subscale in the pre-test and the post-test, T-test has been conducted. The test results are listed in the Table 6. 
Table 6. T-test results of Pedagogical Content Knowledge Subscale of the TPACK Survey

\begin{tabular}{llcllll}
\hline Subscale & $\mathbf{N}$ & $\overline{\mathbf{X}}$ & $\mathbf{S}$ & $\mathbf{S d}$ & $\mathbf{t}$ & $\mathbf{p}$ \\
\hline $\begin{array}{l}\text { Pedagogical Content } \\
\text { Knowledge (Pre-Test) }\end{array}$ & 37 & 21.22 & 7.32 & & & \\
\hline $\begin{array}{l}\text { Pedagogical Content } \\
\text { Knowledge (Post-Test) }\end{array}$ & 37 & 25.87 & 5.05 & & 3.47 & .001 \\
\hline
\end{tabular}

When Table 6 is analyzed, it can be said that the pre-test and the post-test scores of teacher candidates participated in the study have been differentiated significantly for Pedagogical Content Knowledge subscale of the TPACK Survey and it is obvious that the post-test scores of the teacher candidates have been made a differentiation when compared to the pre-test scores $(\mathrm{t}=3.47$, $\mathrm{p}=.001<.05)$.

After collecting Turkish teacher candidates scores they got from the survey's Technological Content Knowledge subscale in the pre-test and the post-test, T-test has been conducted. The test results are listed in the Table 7.

Table 7. T-test results of Technological Content Knowledge Subscale of the TPACK Survey

\begin{tabular}{lcccccc}
\hline Subscale & N & $\overline{\mathbf{X}}$ & S & Sd & t & p \\
\hline $\begin{array}{l}\text { Technological } \\
\begin{array}{l}\text { Content Knowledge } \\
\text { (Pre-Test) }\end{array}\end{array}$ & 37 & 11.41 & 4.49 & & & \\
\hline $\begin{array}{l}\text { Technological } \\
\begin{array}{l}\text { Content Knowledge } \\
\text { (Post-Test) }\end{array}\end{array}$ & 37 & 14.81 & 3.02 & & 3.73 & .001 \\
\hline
\end{tabular}

When Table 7 is analyzed, it can be said that the pre-test and the post-test scores of teacher candidates participated in the study have been differentiated significantly for Technological Content Knowledge subscale of the TPACK Survey and it is obvious that the post-test scores of the teacher candidates have been made a differentiation when compared to the pre-test scores $(\mathrm{t}=3.73, \mathrm{p}=.001<.05)$.

After collecting Turkish teacher candidates scores they got from the survey's TPACK subscale in the pre-test and the post-test, T-test has been conducted. The test results are listed in the Table 8.

Table 8. T-test results of Technological Pedagogical Content Knowledge Subscale of the TPACK

\begin{tabular}{llcllll} 
& \multicolumn{7}{c}{ Survey } & \\
\hline Subscale & $\mathbf{N}$ & $\overline{\mathbf{X}}$ & $\mathbf{S}$ & Sd & t & p \\
\hline TPACK (Pre-Test) & 37 & 13.92 & 5.32 & \multirow{2}{*}{36} & 4.18 & .000 \\
\hline TPACK (Post-Test) & 37 & 18.32 & 4.14 & & & \\
\hline
\end{tabular}

When Table 8 is analyzed, it can be said that the pre-test and the post-test scores of teacher candidates participated in the study have been differentiated significantly for TPACK subscale and it is obvious that the post-test scores of the teacher candidates have been made a differentiation when compared to the pre-test scores $(\mathrm{t}=4.18, \mathrm{p}=.000<.05)$. 


\section{Discussion and Conclusion}

When interpreted the findings of two applications of the TPACK Survey, TPACK levels of Turkish teacher candidates who participated in the study have been differentiated significantly in terms of all the subscales of the survey (Technology Knowledge, Pedagogy Knowledge, Content Knowledge, Technological Pedagogical Knowledge, Pedagogical Content Knowledge, Technological Content Knowledge, Technological Pedagogical Content Knowledge) according to the pre-test and the post-test results. For all the subscales of the survey, Turkish teacher candidates' post-test scores have been shown an improvement than the pre-test scores.

As shown in this study, TPACK pre-test scores of teacher candidates are low when each sub-factor is examined one by one and each sub-factor varies positively as seen in post-test scores emerged after the ITMD course. The lowlines of teacher candidates TPACK pre-test scores in the beginning, can be considered normal when it is beared in mind that they are studying in second grade. Because these students have taken very limited number of courses related to the fields of both technology and education due to their terms. However, when the course structure of the ITMD, the implementation process and the term of the course taken are considered, either the contribution of ITMD to the development of the knowledge or technological and pedagogical practices, tools and materials used, methods, techniques and approaches. Undoubtedly, the course instructor's effect on the process very important. Unfortunately it's not possible to create a positive difference on students with faculty members lacking this skills. At this point, it is not an acceptance that the accuracy of the elements forming Technological Pedagogical Content Knowledge is confirmed. However, it is pointed out that these are useful and helpful knowledge (Koehler and Mishra, 2008). On the other hand, for the integration of ICT to the schools, the integration of ICT to the process of teacher education is crucial (Göktaş, Yıldırım and Yıldırım, 2009).

Harris, Mishra and Koehler (2009) have been stated that TPACK model plays a leading role on the subject of teachers' needs about technology, pedagogy and content in order to ensure professional development of teachers. In conclusion, as stated by Harris, Mishra and Koehler (2009), in order to provide professional development of teachers, in the emergence of the result of TPACK leads a guiding role about teachers' needs respecting technology, pedagogy and content in the teacher candidate education, ITMD course is notably important for TPACK model as well as the general approach and skills set forth in the process of this course, the use of TPACK model and taking into account the expertise factor in the lessons domain-specific methods and approaches are taught, are important for satsifying the need of teachers comply with the requirements of our era.

\section{Recommendations for Further Research}

Mixed methods studies, which is a combination of methods both quantitative and qualitative techniques used together, can be carried out to observe teacher candidates' TPACK development in detail.

\section{References}

Angeli, C., \& Valanides, N. (2005). Preservice elementary teachers as information and communication technology designers: an instructional systems design model based on an 
expanded view of pedagogical content knowledge. Journal of Computer Assisted Learning, 21(4), 292-302.

Angeli, C., \& Valanides, N. (2009). Epistemological and methodological issues for the conceptualization, development, and assessment of ICT-TPACK: advances in technological pedagogical content knowledge (TPACK). Computers \& Education, 52(1), 154-168.

Archambault, L. M., \& Barnett, J. H. (2010). Revisiting technological pedagogical content knowledge: Exploring the TPACK framework. Computers \& Education, 55(4), 1656-1662.

Archambault, L., \& Crippen, K. (2009). Examining TPACK among K-12 online distance educators in the United States. Contemporary Issues in Technology and Teacher Education, 9(1), 71-88.

Archambault, L., \& Oh-Young, C. (2009, March). Putting the T in PCK: Exploring the nature of the TPACK framework among K-12 online educators using a web-based survey. In Society for Information Technology \& Teacher Education International Conference (Vol. 2009, No. 1, pp. 4008-4014).

Baxter, J. A. \& Lederman, N. G. (1999). Assessment and Measurement of Pedagogical Content Knowledge. In J. Gess-Newsome \& N. G. Lederman (Eds.), Examining pedagogical content knowledge (pp. 147-161). Dordrecht: Kluwer.

Beaudin, L., \& Hadden, C. (2004). Developing Technopedagogical Skills in Pre-service Teachers. In World Conference on E-Learning in Corporate, Government, Healthcare, and Higher Education (Vol. 2004, No. 1, pp. 492-498).

Becker, H. J. (2001). How are teachers using computers in instruction. In annual meeting of the American Educational Research Association, Seattle, WA.

Brand, G. A. (1998). What research says: Training teachers for using technology. Journal of staff development, 19, 10-13.

Burgoyne, N., Graham, C. R., \& Sudweeks, R. (2010). The validation of an instrument measuring TPACK. In D. Gibson, \& B. Dodge (Eds.), Proceedings of society for information technology \& teacher education international conference 2010 (pp. 3787-3794). Chesapeake, VA: AACE.

Büyüköztürk, Ş.(2007). Sosyal bilimler için veri analizi el kitabı. Ankara: Pegem-A Yayıncılık.

Çağıltay, K., Çakıroğlu, J., Çağıltay, N. ve Çakıroğlu, E. (2001). Öğretimde Bilgisayar Kullanımına İlişskin Öğretmen Görüşleri. Hacettepe Üniversitesi Eğitim Fakültesi Dergisi,21, 19-28.

Chai, C. S., Ling Koh, J. H., Tsai, C. C., \& Lee Wee Tan, L. (2011). Modeling primary school preservice teachers' Technological Pedagogical Content Knowledge (TPACK) for meaningful learning with information and communication technology (ICT). Computers \& Education, 57(1), 1184-1193.

Cochran, K. F. (1991). Pedagogical Content Knowledge: A Tentative Model for Teacher Preparation.

Cox, S. (2008). A conceptual analysis of technological pedagogical content knowledge. Brigham Young University.

Cox, S., \& Graham, C. R. (2009). Diagramming TPACK in practice: using and elaborated model of the TPACK framework to analyze and depict teacher knowledge. TechTrends, 53 (5), 60-69. 
Davis, K. S., \& Falba, C. J. (2002). Integrating Technology in Elementary Preservice Teacher Education: Orchestrating Scientific Inquiry in Meningful Ways. Journal of Science Teacher Education, 13(4), 303-329.

Dawson, K., Pringle, R., \& Lott Adams, T. (2003). Providing links between technology integration, methods courses, and school-based field experiences: A curriculum-based and technology-enhanced microteaching. Journal of Computing in Teacher Education, 20(1), 41-47.

Erdogan, A., \& Sahin, I. (2010). Relationship between math teacher candidates' Technological Pedagogical And Content Knowledge (TPACK) and achievement levels. Procedia-Social and Behavioral Sciences, 2(2), 2707-2711.

Gess-Newsome, J. (1999). Pedagogical content knowledge: An introduction and orientation. In Examining pedagogical content knowledge (pp. 3-17). Springer Netherlands.

Goktas, Y., Yildirim, S., \& Yildirim, Z. (2009). Main Barriers and Possible Enablers of ICTs Integration into Pre-service Teacher Education Programs. Journal of Educational Technology \& Society, 12(1).

Graham, C. R. (2011). Theoretical considerations for understanding technological pedagogical content knowledge (TPACK). Computers \& Education, 57(3), 1953-1960.

Graham, C. R., Burgoyne, N., Cantrell, P., Smith, L., St. Clair, L., \& Harris, R. (2009). TPACK Development in Science Teaching: Measuring the TPACK Confidence of Inservice Science Teachers, TechTrends, Special Issue on TPACK, 53(5), 70-79.

Harris, J., Mishra, P., \& Koehler, M. (2009). Teachers' technological pedagogical content knowledge and learning activity types: curriculum-based technology integration reframed. Journal of Research on Technology in Education, 41(4), 393-416.

Hewitt, J. (2008). Reviewing the handbook of technological pedagogical content knowledge (TPCK) for educators. Canadian Journal of Science, Mathematics, and Technology Education, 8(4), 355-360.

Jonassen, D., ve Reeves, T. (1996). Leaming with Technology: Using Computers as Cognitiye Tools. In D. 1-I. Jonassen (Ed.), Handbook of Research on Educational Communications and Technology (pp. 693-719).

Karasar, N. (2006). Bilimsel araştırma yöntemleri. Ankara: Nobel Yayın Dağıtım.

Koehler, M. J., \& Mishra, P. (2005). What happens when teachers design educational technology? The development of technological pedagogical content knowledge. Journal of educational computing research, 32(2), 131-152.

Koehler, M. J., \& Mishra, P. (2008). Introducing TPACK. In AACTE. (Ed.), Handbook of technological pedagogical content knowledge (TPACK) for educators (pp. 3-29). New York: Routledge.

Koehler, M., \& Mishra, P. (2009). What is technological pedagogical content knowledge (TPACK)?. Contemporary Issues in Technology and Teacher Education, 9(1), 60-70.

Koh, J., Chai, C. S., \& Tsai, C. C. (2010). Examining the technological pedagogical content knowledge of Singapore preservice teachers with a large-scale survey. Journal of Computer Assisted Learning, 26, 563-573.

Loveless A. \& Dore B. eds (2002) ICT in the Primary School. Open University Press, Buckingham, UK. 
Margerum-Leys, J., \& Marx, R. W. (2002). Teacher knowledge of educational technology: A case study of student/mentor teacher pairs. Journal of Educational Computing Research, 26(4), 427-462.

Mazman, S. G., \& Koçak Usluel, Y. (2011). Bilgi ve iletişim teknolojilerinin öğrenme-öğretme süreçlerine entegrasyonu: modeller ve göstergeler. Eğitim Teknolojisi: Kuram ve Uygulama, 1, 62-79.

Mishra, P., \& Koehler, M. J. (2006). Technological pedagogical content knowledge: a framework for teacher knowledge. Teachers College Record, 108(6), 1017-1054.

Mumtaz, S. (2000). Factors affecting teachers' use of information and communications technology: a review of the literature. Journal of information technology for teacher education, 9(3), 319-342.

Niess, M. L. (2011). Investigating TPACK: Knowledge growth in teaching with technology. Journal of educational computing research, 44(3), 299-317.

Pamuk, S. (2011). Understanding preservice teachers' technology use through TPACK framework. Journal of Computer Assisted Learning, 28: 425-439. doi: 10.1111/j.13652729.2011.00447.x

Pringle, R. M., Dawson, K., \& Adams, T. (2003). Technology, science and preservice teachers: Creating a culture of technology-savvy elementary teachers. Action in Teacher Education, 24(4), 46-52.

Sahin, I. (2011). Development of survey of technological pedagogical and content knowledge (TPACK). Turkish Online Journal of Educational Technology-TOJET, 10(1), 97-105.

Schmidt, D. A., Baran, E., Thompson, A. D., Mishra, P., Koehler, M. J., \& Shin, T. S. (2009). Technological pedagogical content knowledge (TPACK): the development and validation of an massessment instrument for preservice teachers. Journal of Research on Technology in Education, 42(2), 27.

Segall, A. (2004). Revisiting pedagogical content knowledge: the pedagogy of content/the content of pedagogy. Teaching and Teacher Education, 20(5), 489-504.

Shulman, L. S. (1986). Those who understand: Knowledge growth in teaching. Educational Researcher, 15(2), 4-14. doi:10.3102/0013189X015002004

Shulman, L. S. (1987). Knowledge and teaching: Foundations of the new reform. Harvard Educational Review, 57(1), 1-22.

Thompson, A. D., Schmidt, D. A., \& Davis, N. E. (2003). Technology collaboratives for simultaneous renewal in teacher education. Educational Technology Research and Development, 51(1), 73-89.

Timur, B., \& Taşar, M. F. (2011). Teknolojik Pedagojik Alan Bilgisi Öz Güven Ölçeğinin (TPABÖGÖ) Türkçe'ye Uyarlanması. University of Gaziantep Journal of Social Sciences, 10(2).

Turkish Education Association (2009). Öğretmen Yeterlikleri[Teachers’ Sufficiency], Ankara: Adım Okan Matbaacılık.

Usta, E., \& Korkmaz, Ö. (2010). Öğretmen adaylarının bilgisayar yeterlikleri ve teknoloji kullanımına ilişskin algıları ile öğretmenlik mesleğine yönelik tutumları.Uluslararası İnsan Bilimleri Dergisi, 7(1), 1335-1349.

Yurdakul, I. K., Odabaşı H. F. (2013). Teknopedagojik Eğitim Modeli. Yurdakul (Ed.), Teknopedagojik Eğitime Dayalı Öğretim Teknolojileri ve Materyal Tasarımı (ss. 39-69). Ankara: An1. 
Yurdakul, I. K., Odabasi, H. F., Kilicer, K., Coklar, A. N., Birinci, G., \& Kurt, A. A. (2012). The development, validity and reliability of TPACK-deep: A technological pedagogical content knowledge scale. Computers \& Education,58(3), 964-977.

Yurdakul, I. K., Odabasi, H. F., Sahin, Y. L., \& Coklar, A. N. (2013). A TPACK Course for Developing Pre-Service Teachers' Technology Integration Competencies: From Design and Application to Evaluation. In J. Keengwe (Ed.), Research Perspectives and Best Practices in Educational Technology Integration (pp. 242-269). Hershey, PA: Information Science Reference. doi:10.4018/978-1-4666-2988-2.ch013 